\title{
Global e-commerce - consumer habits and perceived opportunity for professional realization of the first-year students in economics
}

\author{
Maria Kicheva ${ }^{1}$, Boryana Dimitrova ${ }^{1, *}$ \\ ${ }^{1}$ South-West University “Neofit Rilski”, Faculty of Economics, Department of Economics, 2700 \\ Blagoevgrad, Bulgaria
}

\begin{abstract}
Globalization is a process with serious implications for the well-being of humankind. The development of electronic technologies and hardware has led to the emergence and expansion of global e-commerce which allows people to meet their needs for certain goods and receive financial means to do that. This article points to the results of a study of online buying habits and perceived opportunity for professional realization in e-commerce of first-year students in Economics at a smaller economic faculty in Southeast Europe, born in the late $\mathrm{Y}$ generation, with a minimum period of higher education in majors other than e-commerce. The relationship with the education and training, required to carry out these activities was specifically sought. The method of self-administered survey was used. 58 usable questionnaires were collected. Results show that respondents buy online mostly clothes, shoes, cosmetics and electronics and pay usually by bank cards; the main reasons for this kind of purchasing being the lower price and non-availability of the goods otherwise. Only $12.07 \%$ of the respondents have conducted commercial sales via the Internet and out of them $-57.1 \%$ are satisfied with the income, but only at the-pocket-money-level. $36.2 \%$ of all respondents are ready to seek training in order to be able to earn a living in this way, which points to a niche in the educational services market.
\end{abstract}

\section{Introduction}

At the heart of human life is meeting one's needs. This is also the main reason for starting a business - on the one hand to create goods that meet the needs of customers and on the other hand to make a profit that will allow the owner of the company to meet the most of their needs and to the highest extent.

From this point of view, the study and analysis of the needs of the buyers and the peculiarities of their purchasing behaviour, incl. by generational characteristics, is a fundamental necessity of every business, especially the companies in the trade sector,

\footnotetext{
*Corresponding author: $\underline{b}$ dimi@abv.bg
} 
especially since trade is the major component of GDP nowadays: according to Worldbank data in 2017 trade had a $57.88 \%$ share in the world's GDP [1].

\subsection{Development of trade}

Trade is an important element of the labour distribution system. Through the trade process, the exchange of goods and money between buyers and sellers is realized. In this sense, it is a major factor in meeting the needs of individuals and businesses, on the one hand, and on the other, it is a main area in which they earn income to buy the necessary goods later.

Stoichev [2] points out that the development of trade also necessitates the need for a universal means of exchange, and in the Akkadian kingdom (20-19 c. BC), role of such was given to silver and barley with a fixed ratio between them. As a result, in the New Babylonian Kingdom (7-6 c. BC), foreign and domestic trade developed actively. Later, around the 5th century BC, in ancient Greece, after the reforms of Pericles, maritime trade flourished, serving large-scale craftsmanship - mainly raw materials were imported and finished products were exported. In Ancient Rome, a gigantic market was formed, stipulating active trade beyond the size of those in Ancient Greece. After the destruction of the Roman Empire, many trade links were destroyed. During the Early Middle Ages, trade lost its lustre and was not a powerful source of wealth as in Ancient Rome, which is also associated with the negative moral and ethical evaluation it received from Augustine the Blessed. It was not until the 12 th century $\mathrm{AD}$, when the church changed its view of trade as a result of the changes in socio-economic reality: the emergence of cities in Europe and the expansion of trade. In the 15-17th centuries, commercial capital dominated Europe, which led to the establishment of the mercantile school of economic thought. Its representatives considered that foreign trade as a way of realizing the national product is at the heart of increasing the nation's wealth and that the central government needs to pursue a protectionist policy in its defence; they are the first to associate wealth with exchange value. A look at the historical past shows that mercantile policy became the economic basis of capitalism.

Later, the representatives of the classical school Adam Smith and David Ricardo managed to explain the main competitive advantages in the production of the goods that underlie international trade. Smith defined the principle of absolute advantages, according to which the advantage in the production of a product is available when less labour is spent on creating a unit of product than in the other country, and Ricardo - the principle of comparative advantages: the advantage is present when the alternative costs of producing the product are lower than those of the other country. Related to this, a recent study of Sneppen \& Bornholdt [3] suggests "that the transition from a local economy to a global economy is naturally driven by reduced transportation costs and an increased information horizon".

Global commerce, as it is known today, dates back to the 16th and 17th centuries, when large trading companies were founded in Great Britain, Spain, Portugal and the Netherlands.

The emergence of internet commerce is the result of the development of information technology. Tkacz \& Kapczynski [4] state that the first demonstration of an online shopping system was made in 1979.

The link between globalization and e-commerce was studied among others, by Kraemer, Gibbs \& Dedrick [5], who showed that "globalization leads to both greater scope of ecommerce use and improved performance, measured as efficiency, coordination, and market impacts".

The importance of international trade for the prosperity of society has become increasingly clearer over time. This can be considered as one of the main reasons for the 
creation of the international organizations European Coal and Steel Union (1951) and Euroatom (1957), which are the basis of today's European Union (1992). According to WTO data [6] in 2017, the European Union was the most dynamic regional trade agreement (RTA) accounting for one third of world exports. In the same year, world merchandise exports were US \$17,198 billion (an increase of 133.07\% since 2003). In addition, the importance of e-commerce is increasing every year: in 2016, global e-commerce totalled an increase of $43.52 \%$ since 2012 to US \$ 27.7 trillion, of which US \$ 3.8 trillion is B2C (business-to-consumer).

\subsection{The $Y$ generation and its consumer habits}

Members of Generation Y, or the "Millennials" throughout the literature, are generally confirmed by the authors to have been born between the years 1980 and 2000 and they use technology in their daily lives, namely all forms of social media and communication via cell phones, laptops, tablets. [7-10] Currently Gen Y members are between 18 and 39 years of age and that makes them the major part of college students.

Smith [11] points out that studying them is important and relevant because of their purchasing power and their behaviour, which is different from the one of previous generations. Reisenwitz \& Fowler [12] state that "generation Y is becoming more important to marketers as its members continue to enter the workforce". Giovannini, Xu \& Thomas [13] emphasize the increasing importance of Millennial segment for the luxury market in the USA. As Smith [14] shows "U.S. basic cable channels are increasingly directing their brands toward millennials due to the increased economic importance of this demographic group".

Recent studies show measurable differences in Millennials purchasing behaviour. For example, Kim [15] found out that they "exhibited significantly more frequent purchases of luxury fashion goods for all retail types - both brick-and-mortar and online, as well as upscale and discount-image retailers, compared to older Baby Boomers". According to Eastman \& Liu [16] in comparison to previous generations "the average level of status consumption was highest for Generation Y". Bucic, Harris \& Arli [17] conclude that Millennials "consider discrete motives when making consumption decisions, and are willing to engage in cause-related purchasing to varying degrees".

The study of Wiese \& Kruger [18] focused on the parental influence on consumer and purchase behaviour of Generation Y and found that there is such.

Purani, Kumar \& Sahadev [19] studied the e-loyalty among Gen Y and their findings "suggest that personal characteristics and social influence play more crucial role in deciding the e-loyalty intentions of millennials".

\section{Method}

A self-administered survey instrument was developed to gather information from student respondents about their online buying habits and perceived opportunity for professional realization in e-commerce. Respondents were selected from a single university, more precisely from a smaller economic faculty in Bulgaria. Freshmen in majors other than ecommerce were chosen, namely because of being born at the end of Generation $Y$ and because of their minimal period of higher education.

The first section of the questionnaire gathered demographic information. In addition to the customary questions regarding their nationality, age and gender, students were also asked demographic characteristic questions regarding the place they live permanently, the number of people in their households and the household's income. 
The second section of the questionnaire gathered information about respondents' previous high school education and study of foreign languages.

The third section focused on their online shopping and selling history and perceived opportunity for professional realization in e-commerce. Additional questions about their approval of globalization and the nature of its treats were included.

The surveys were distributed in a variety of business classrooms at the end of the second semester to freshmen students, who have studied both micro- and macroeconomics. 58 usable questionnaires were collected.

\section{Results}

The demographic profile of the respondents is as follows: $74.1 \%$ are women; $89.7 \%$ are Bulgarians by nationality, 5.2\% - Macedonians, 3.4\% - Serbs, $1.7 \%$ - Jordanians; $48.3 \%$ are 19 years old, $37.9 \%$ are 20 years old, $5.2 \%$ are $25,3.4 \%$ are 21 , and $1.7 \%$ are 18,22 and 27 years old each, which gives a median age of 19.5 years; $39.7 \%$ live in a smaller town, $34.5 \%$ in a regional town, $20.7 \%$ in a rural area and $5.2 \%$ in the capital; the approximate median monthly income of a family member is BGN 437.5, in particular: $56.9 \%$ have income in the range 201-500 BGN per person, 20.7\% - in the range 501-1000 BGN per person, $13,8 \%$ in the range $0-200 \mathrm{BGN}$ per person, $8.6 \%$ - over $1000 \mathrm{BGN}$ per person.

All respondents studied English, with $62.1 \%$ self-identified at an average level of language proficiency and 19\% respectively: advanced and beginner; $39.7 \%$ hold a language proficiency certificate. 19 respondents indicated that they had studied 2 foreign languages other than Bulgarian and their native language (if they were not Bulgarian), and 5 - 3 foreign languages except Bulgarian and their native language. These are German, French, Spanish, Russian, Turkish, Greek and Arabic languages.

During their secondary education, $41.4 \%$ of the respondents trained for a profession, with $20.6 \%$ of all 58 respondents for an economic specialty corresponding to the specialty "Business Management and Entrepreneurship" and professional field "Economics", in which they are studying currently at the university (respectively $27.6 \%$ and $72.4 \%$ ). In addition, one respondent has studied in the specialty "E-commerce" and one in the specialty "Economic Informatics".

The survey of respondents' online shopping habits shows that: $79.3 \%$ (46) of them buy goods online; the main sites they buy from are as follows: aliexpress.com $-65.2 \%$ of respondents, sportihobi.com - 19.6\%, sportdepot.bg - 17.4\%, ebay.com - 17.4\%, amazon. com - 10.9\%, emag.bg - 10.9\%, alibaba.com - 4.3\%, shein.com - $2.7 \%$ and cbuy.bg, guess.com, mandmdirect.com, ozone.bg, wish.com, technomarket.bg were cited by $2.2 \%$ (the total is over $100 \%$, as more than one site was allowed to be specified). Typically, respondents buy clothes $(40.8 \%)$, shoes $(24.3 \%)$, cosmetics $(11.7 \%)$, electronics $(10.7 \%)$, home appliances $(5.8 \%)$, books $(3.9 \%)$, toys $(1.9 \%)$. Online purchases of goods for a period not longer than 1 year have made $67.4 \%$ of the respondents, up to 2 years $-10.9 \%$, up to 3 years $-8.7 \%$, up to 4 years $-2.2 \%$, up to 5 years $-10.9 \%$. Number of online purchases: up to 5 have made $37 \%$ of the respondents, between 6 and $20-34.8 \%$, between 21 and $100-$ $23.9 \%$, over $100-4.3 \%$. $87 \%$ of respondents use their foreign language skills when shopping online. They usually buy late at night (78.3\%), 19.6\% during the workday and only $2.2 \%$ in the early morning. Payment is usually made by bank card: debit card $(41.3 \%)$ and credit card (30.4\%), an additional $26.1 \%$ pay with cash on delivery and only $2.2 \%$ with PayPal. Apart for themselves, $84.8 \%$ of the respondents also shop for someone else. $89.1 \%$ regularly review the shipment before paying. So far, $39.1 \%$ of the respondents had no problems with the quality of the goods, and only $6.5 \%$ had frequent problems. In case of problems, they reach an agreement with the trader: always $-42.9 \%$ of the respondents; sometimes $-50 \%$, never $-7.1 \%$. 
The main reasons for buying in this way are: because of the lower price - $63 \%$, receiving a product that is not available otherwise $-52.2 \%$, lack of time to shop in a physical store $-13 \%$, lack of desire for shopping in a physical store $-8.7 \%$.

Only $12.07 \%$ of the respondents took advantage of the opportunity to conduct commercial sales via the Internet. Of these: all sell in Bulgaria and one in other EU countries as well; they ship their goods from China (57.1\%), England (42.9\%) and Bulgaria $(14.3 \%) ; 57.1 \%$ are satisfied with the income from their endeavour, but only at the-pocketmoney-level, the remaining $42.9 \%$ do not find it profitable enough; the initial investment was below BGN 500 for all, with one starting at only BGN $15 ; 57.1 \%$ of them learned to do this activity from a friend, while the other $42.9 \%$ learned via self-study.

Asked if they envisage the opportunity to carry out (respectively continue) online sales business in the future, $50 \%$ refuse, $6.9 \%$ already decided to do it, and the remaining $43.1 \%$ plan to do so eventually. Of those who did not reject the idea (29 respondents), $72.4 \%$ were ready to seek training in order to carry out the activity; $51.7 \%$ know where they could do it, and $37.9 \%$ know how much it will cost them in time and money.

At the end of the poll, $84.5 \%$ of all respondents approve of globalization from the point of view that it provides more opportunities for professional realization and desired purchases. Asked to share how they personally see the threats of globalization, only 3 respondents did so, responding as follows: hindrance to small businesses, possible bankruptcy and unemployment, burdening the state budget, misuse of personal data, fraud.

\section{Discussions}

A closer look at the data shows what we expected as a lower number of online purchases and a shorter period of purchase in this way, given the age of the respondents and the fact that they are still financially dependent on their parents. The usual time of purchase is late evening, which can be explained by their involvement in school activities and other activities during the day, as well as by the fact that most of them have active evening and night life - going out with friends and so on. The main focus of the purchases are clothes and shoes, as they are one way to stand out and show individuality at a not very high income. Unexpectedly, most payments are made with bank cards, incl. credit ones. This indicates a high level of development of banking in the country on the one hand, and suggests that many students use parental cards or ones funded by them. Students demonstrate a high economic culture in purchases, with the majority reviewing the shipment before payment and seeking agreement on quality issues.

An analysis of student online sales shows that, overall, this is not a profitable business for them and is not a widespread way of making money. The reasons for the former can also be found in the fact that, as a whole, those who have tried this opportunity acted amateur - without specialized training and with minimal investment.

Interestingly, many students are open to pursuing this business opportunity in the future and are ready to seek training, but not all of those who are willing know where they can get it and even less know how much it will cost.

Not all students approve of globalization, although it does provide opportunities for professional realization through e-commerce, but even fewer manage to articulate the threats of globalization they see.

\section{Conclusions}

The results of the study show that for the freshmen in the smaller economics faculty in Southeast Europe, e-commerce, the result of globalization and technological progress, is more a means of meeting the needs than of generating income, but they are also open to this 
career opportunity and are ready to receive the training they need. This can be the basis for organizing and offering educational services by universities via the way of masters programs or paid courses and specializations.

This paper is an outcome of RP-B4/19 Economic and legal aspects in the development of globalization in the European Union and Bulgaria.

\section{References}

1. http://api.worldbank.org/v2/en/indicator/NE.TRD.GNFS.ZS?downloadformat=excel

2. B. Stoychev, Classical and Modern Economic Theories - part 1 (University publishing house Neofit Rilski, 2013)

3. K. Sneppen, S. Bornholdt, Globalization in a nutshell. Physical Review E 98, 042314 (2018)

4. E. Tkacz, A. Kapczynski, Internet - Technical Development and Applications, 255. (Springer, 2009)

5. K. Kraemer, J. Gibbs, J. Dedrick, Impacts of Globalization on E-Commerce Use and Firm Performance: A Cross-Country Investigation. The Information Society 21(5), 323-340 (2005)

6. WTO. World trade statistical review 2018 (2018)

7. N. Lee, P. Kotler, Social Marketing: Changing Behaviors for Good. (SAGE Publications, 2016)

8. A. Al-Asfour, L. Lettau, Strategies for Leadership Styles for Multi-Generational Workforce. Journal of Leadership, Accountability and Ethics 11(2), 58-69 (2014)

9. B. Kaifi, N. Khanfar, W. Nafei, M. Kaifi, A Multi-Generational Workforce: Managing and Understanding Millennials. International Journal of Business and Management 7(24), 88-93 (2012)

10. F. Omar, N. Hassan, I. Sallehuddin, N. Abdullah, Gen Y: A Study on Social Media Use and Outcomes. Journal of Management \& Muamalah 6(1), 53-64 (2016)

11. K. Smith, Digital marketing strategies that Millennials find appealing, motivating, or just annoying. Journal of Strategic Marketing 19(6), 489-499 (2011)

12. T. Reisenwitz, J. Fowler, Information Sources and the Tourism Decision-making Process: An Examination of Generation X and Generation Y Consumers. Global Business Review (August 2019)

13. S. Giovannini, Y. Xu, J. Thomas, Luxury fashion consumption and Generation Y consumers. Journal of Fashion Marketing and Management 19(1), 22-40 (2015)

14. A. Smith, Pursuing "Generation Snowflake": Mr. Robot and the USA Network's Mission for Millennials. Television \& New Media 20(5), 443-459 (2019)

15. J. Kim, Luxury fashion goods ownership and collecting behavior in an omni-channel retail environment. Research Journal of Textile and Apparel 23(3), 212-231 (2019)

16. J. Eastman, J. Liu, The impact of generational cohorts on status consumption: an exploratory look at generational cohort and demographics on status consumption. Journal of Consumer Marketing 29(2), 93-102 (2012)

17. T. Bucic, J. Harris, D. Arli, Ethical Consumers Among the Millennials: A CrossNational Study. Journal of Business Ethics 110(1), 113-131 (2012)

18. M. Wiese, L. Kruger, Parental influence on consumer and purchase behaviour of Generation Y. Journal of Family Ecology and Consumer Sciences 44, 21-31 (2016) 
19. K. Purani, D. Kumar, S. Sahadev, e-Loyalty among millennials: Personal characteristics and social influences. Journal of Retailing and Consumer Services 48(C), 215-223 (2019) 